\title{
Armin Langer
}

\section{Educating the Jews to Become Germans}

\author{
Naftali Herz Homberg's 'Civilizing Mission' to the Jewish \\ Community of Galicia
}

\begin{abstract}
The isolation of Jews in the German states and territories began decreasing in the late eighteenth and early nineteenth centuries. At the same time, Jews started to represent a 'problem' for the enlightened concept of a modern society with its uncompromising demand for cultural homogeneity. Philosophers of the Enlightenment, such as Kant, implied that Jewish religious observance stood for a separatist interpretation of religion and wanted to 'educate' the Jews to be Germans. This 'education' was also promoted by enlightened Jews, such as the Austro-Bohemian educator Naftali Herz Homberg (1749-1841), who was the superintendent of German-Jewish schools of Galicia. In my paper, I analyze Homberg's magnum opus Bne-Zion which was meant to function as a catechism for the enlightened Jewish youth. The intention of this paper is to add a new sociological perspective to the Homberg bibliography, with an emphasis on intergroup relations between the Jewish minority and the non-Jewish majority. I look into the assimilationist policies of the German Enlightenment and the Austrian Empire, and try to show how these were internalized by Homberg in his work.
\end{abstract}

Keywords: Acculturation; Enlightenment, Austria; Galicia; Education

Zusammenfassung: Ab dem Ende des 18. und Anfang des 19. Jahrhunderts nahm die Isolation der Juden in den deutschen Ländern ab. Gleichzeitig stellten sie in den Vorstellungen der Aufklärung über eine moderne Gesellschaft mit ihrer kompromisslosen Forderung nach kultureller Homogenität ein ,Problem dar. Philosophen wie Kant meinten, dass jüdische religiöse Praxis für eine separatistische Interpretation der Religion stehe, und wollten deshalb die Juden zu Deutschen ,erziehen'. Diese ,Erziehung' wurde auch von aufgeklärten Juden gefördert, wie zum Beispiel von dem österreichischböhmischen Pädagogen Naftali Herz Homberg (1749-1841), der Superintendent der deutsch-jüdischen Schulen in Galizien war. Der Aufsatz behandelt Hombergs Opus magnum Bne-Zion, das als Katechismus für die aufgeklärte jüdische Jugend dienen sollte. Der Homberg-Forschung soll damit eine neue, soziologische Perspektive hinzugefügt werden, wobei der Schwerpunkt auf den Beziehungen zwischen der jüdischen Minderheit und der nichtjüdischen Mehrheit liegt. Insbesondere steht die assimilatorische Politik der deutschen Aufklärung und des österreichischen Staates im Mittelpunkt. Es wird gezeigt, wie Homberg diese Agenda in seinem Buch reproduzierte.

Schlagwörter: Akkulturation; Aufklärung; Österreich; Galizien; Erziehung

Armin Langer, M.A., Humboldt-Universität zu Berlin, Institut für Sozialwissenschaften, langerar@huberlin.de 


\section{Introduction}

Jews have lived apart from Christians in Europe, including the Austrian territories, for centuries. ${ }^{1}$ As with other ethnic groups in society, they possessed corporate status having their own privileges and obligations. Their communities enjoyed judicial autonomy, enabling rabbinical courts to enforce Jewish law. Interaction with the nonJewish world was minimal. This all changed at the beginning of the late eighteenth and early nineteenth centuries when, as a consequence of the Enlightenment, the isolation of Jews began to decrease. Austrian Emperor Joseph II's 1782 Edict of Tolerance, which promised freedom of worship and unity, was a major step towards their formal equality. It was initially implemented in the province of Lower Austria, and subsequently extended to other parts of the Empire. ${ }^{2}$ The edict declared:

Von Antretung Unserer Regierung an haben Wir es einen Unserer vorzüglichsten Augenmerke seyn lassen, daß alle Unsere Unterthanen ohne Unterschied der Nazion und Religion, sobald sie in Unseren Staaten aufgenommen und geduldet sind, an dem öffentlichen Wohlstande, den Wir durch Unsere Sorgfalt zu vergrößern wünschen, gemeinschaftlichen Antheil nehmen, eine gesetzmäßige Freyheit genießen und auf jedem ehrbaren Wege zu Erwerbung ihres Unterhalts und Vergrößerung der allgemeinen Aemsigkeit kein Hindernis finden sollten. ${ }^{3}$

Enlightened absolutism, as practiced by late eighteenth-century Austrian rulers, did not believe in civil or religious equality in the modern sense. Nevertheless, Joseph II's edict extended privileges enjoyed by other subjects to the Jews. This was achieved by granting the Jews advances in their legal status through administrative reforms. The Emperor wanted to integrate them into the state's social and economic systems; in other words to turn them into 'useful subjects'. ${ }^{4}$

Legal advances did not come with social acceptance, however, Jews, and their social status, had been a matter of public discussion since the beginning of the Enlightenment. They constituted a 'problem' in the concept of an enlightened society with its demand for cultural homogeneity. Kant, Fichte, Herder and others implied that Jewish religious observances stood for disintegration. Kant sought to deprive Judaism of its

1 I would like to thank my supervisor, Prof. Dr. Naika Foroutan (Humboldt University of Berlin), and Prof. Dr. Michael Laurence Miller (Central European University) who provided insight that assisted the research, although they may not agree with all of the interpretations of the paper.

2 Cf. Mordechai Eliav: Jüdische Erziehung in Deutschland im Zeitalter der Aufklärung und der Emanzipation. Münster 2001, 235.

3 Toleranzpatent für die Juden in Wien und in Niederösterreich. Wien, 2. Januar 1782. In: Harm Klueting (Ed.): Der Josephinismus. Ausgewählte Quellen zur Geschichte der theresianisch-josephinischen Reformen. Darmstadt 1995 (Ausgewählte Quellen zur deutschen Geschichte der Neuzeit 12a), 275-279, here 275.

4 Cf. Israel Bartal: The Jews of Eastern Europe, 1772-1881. Philadelphia/PA 2005, 73; Hamish M. Scott: Reform in the Habsburg Monarchy, 1740 -90. In: Idem (Ed.): Enlightened Absolutism. Reform and Reformers in Later Eighteenth-Century Europe. New York 1990, 170. 
status as a religion and claimed that, due to its "statutarischer Gesetze" - that is, expressions of religious identity such as rituals - it was just a political organization: "Der jüdische Glaube [...] ist eigentlich gar keine Religion, sondern bloß Vereinigung einer Menge Menschen, die, da sie zu einem besonderen Stamm gehörten, sich zu einem gemeinen Wesen unter bloß politischen Gesetzen, mithin nicht zu einer Kirche formten." In order to become 'useful' citizens, the German Enlightenment demanded that the Jews assimilate, leave their cultural and religious traits and values behind ${ }^{6}$ and, ideally, convert to Christianity. ${ }^{7}$ As Jacob Katz put it, ${ }^{8}$ it was not the missionaries anymore who tried to convince Jews of the Christian truth, but enlightened philosophers and lawmakers who promoted this hierarchical order as the only way to social participation. ${ }^{9}$

Joseph II also introduced his reforms in conjunction with this assimilationist agenda, that is, an agenda expecting Jews to become like members of the dominant society. ${ }^{10}$ Jews were required to take German surnames instead of their traditional patronymic names. They had to abandon their traditional dress and wear contemporary garments, had to provide a quota of conscripts to the army and give up the authority of the Jewish community courts. ${ }^{11}$ Joseph II believed that if the royal subjects were enlightened, i.e. educated, it was to the advantage of the state apparatus. For enlightened absolutist rulers like him, education was the key to promoting Jewish assimilation into the non-Jewish majority society, assuming that the latter was more advanced. We can also see this paternalistic attitude towards the Jews, and their norms, in the 1782 Edict of Tolerance:

Da nun mit dieser Unserer gnädigsten Absicht die gegen die jüdische Nazion überhaupt in Unseren Erbländern und insbesondere zu Wien und in Niederösterreich bestehenden Gesetze und sogenannten Judenordnungen nicht durchaus zu vereinbaren sind, so wollen Wir dieselben kraft gegenwärtigen Patents insofern abändern, als es die Verschiedenheit der Zeit und Umstände nöthig machen. [...] Da Wir die jüdische Nazion hauptsächlich durch bessere Unterrichtung und Aufklärung ihrer Jugend und durch Verwendung auf Wissenschaften, Künste und Handwerke dem Staate nützlicher und brauchbarer zu machen, zum Ziele nehmen, so erlauben und befeh-

\footnotetext{
5 Immanuel Kant: Die Religion innerhalb der Grenzen der blossen Vernunft. In: Idem: Werke in zehn Bänden. Ed. by Wilhelm Weischedel. Vol. 7: Schriften zur Ethik und Religionsphilosophie. Zweiter Teil. Sonderausgabe. Darmstadt 1983, 645-879, here $789 \mathrm{f}$.

6 Cf. John W. Berry: Immigration, Acculturation, and Adaptation. In: Applied Psychology: An International Review 46/1 (1997), 5-68, here 10.

7 Cf. Armin Langer: Vergeblich integriert? Rabbiner Samson Raphael Hirsch und die jüdische Akkulturation im 19. Jahrhundert. Berlin 2019, 23.

8 Cf. Jakob Katz: Zur Assimilation und Emanzipation der Juden. Ausgewählte Schriften. Darmstadt 1982, 94.

9 Cf. Jonathan M. Hess: Germans, Jews and the Claims of Modernity. New Haven/CT-London 2002, 148, 157.

10 Cf. Berry, Immigration, Acculturation, and Adaptation (cf. n. 6), 11.

11 Cf. Bartal, The Jews of Eastern Europe (cf. n. 4), 73f.
} 
len Wir gnädigst, den tolerierten Juden in jenen Orten, wo sie keine eignen deutschen Schulen haben, ihre Kinder in die christlichen Normal und Realschulen zu schicken [...]. ${ }^{12}$

The school was considered to be a key element in transferring values of enlightened absolutist rulers and in maintaining societal hierarchies. This process had already begun with Joseph II's mother, Empress and Queen Maria Theresa, who had centralized education and made it the state's responsibility, rather than that of religious institutions. She was the first to introduce compulsory education, for boys and girls alike, in 1774. It was under Maria Theresa's rule that the first general school textbook, a sort of state catechism, was published in the Austrian territories under the title Lesebuch für die Schüler der deutschen Schulen in den $k$. $k$. Staaten. It was written by Johann Ignaz Felbiger, a pedagogue whose work concentrated on moral principles. Under Joseph II, further textbooks were developed and extended the duties of subjects towards their rulers. ${ }^{13}$ According to Louis Althusser, the ruling class - in our case the Austrian feudal order - could not "hold state power over a long period without at the same time exercising its hegemony over and over again in the Ideological State Apparatuses.” Althusser named several carriers of these Ideological State Apparatuses, namely: family, legal structures and culture. But he emphasized that "no other Ideological State Apparatus [...] has a captive audience of all the children [...] for as many years as the schools do, eight hours a day, six days out of seven." Schools were and have been of key importance in turning citizens into "useful" subjects. ${ }^{14}$

Joseph II's educational reforms were embraced not only by proponents of the German Enlightenment but also by members of the Haskalah, a Jewish intellectual movement that developed in the late eighteenth century around the Berlin philosopher Moses Mendelssohn. Followers of this movement, who were also known as 'maskilim', encouraged Jews to acculturate into European culture. This acculturation ranged from clothing and everyday manners to the presentation of one's loyalty to the sovereign. The maskilim advocated rational thinking and encouraged Jews to study traditionally non-Jewish subjects, engage in historically non-Jewish spaces and learn non-Jewish European languages. They established new Jewish schools, which incorporated secular education, in Berlin and elsewhere; and founded new Hebrew periodicals, such as the Ha-Measef, to broaden Jewish cultural horizons. While Mendelssohn himself advocated only cultural adaptation and not religious reforms of Judaism, this soon became a

12 Toleranzpatent (cf. n. 3), 275, 277.

13 Cf. Rachel Manekin: The Moral Education of Jewish Youth. The Case of Bne Zion. In: Ivo Cerman, Rita Krueger, Susan Reynolds (Ed.): The Enlightenment in Bohemia. Religion, Morality and Multiculturalism. Oxford 2011, 273-294, here 274f.; Helmut Seel: Die österreichische Schule am Ende der “Moderne”. In: Oskar Achs, Rupert Corazza, Wolfgang Gröpel, Eva Tesar (Ed.): Bildung - Promotor von Gleichheit oder Ungleichheit? Wien 2006, 25-38, here 29.

14 Louis Althusser: On the Reproduction of Capitalism. Ideology and Ideological State Apparatus. London 2014, 146, 243-245. See also the article by Benedikt Stimmer in this issue. 
bone of contention between moderate and radical maskilim. Joseph II's court turned to one of these radical maskilim to help implement the reforms: Naftali Herz Homberg. ${ }^{15}$

\section{Herz Homberg and the Haskalah movement}

Herz Homberg (1749 - 1831) was born in the village of Lieben (Libeň), Bohemia in the Austrian Empire, which today is part of Prague, Czechia. At the age of ten he was already a rabbinical student at Yechezkel Landau's yeshivah, Landau being an influential Prague-based authority in Jewish law. As a stringent traditional Jew, Landau condemned the emerging Haskalah movement in his public sermons. ${ }^{16}$ Homberg also came from a traditional Jewish family, only learning to write in German at the age of eighteen. ${ }^{17}$ However, his life took a different turn after he got to know maskilim in Breslau (Wrocław), Hamburg and Berlin. Homberg passed from Jewish traditionalism to the Haskalah. He even contributed to Mendelssohn's famous annotated German translation of the Torah. ${ }^{18}$ As the Berlin philosopher's grandson, the geographer Georg Benjamin Mendelssohn, stated: Homberg worked in the family's house for three years as a private tutor of Moses Mendelssohn's son and Georg's father, Joseph. During this time he also learned from Moses Mendelssohn himself, although he ended up being one of the most radical maskilim, unlike the moderate Mendelssohn. ${ }^{19}$ According to other sources, Homberg lived for four or five years with the Mendelssohns. ${ }^{20}$ Georg Mendelssohn might have downplayed Homberg's time in his grandfather's house because of his ambivalent feelings towards Homberg; he even stressed that Moses Mendelssohn was dissatisfied with Homberg's Torah commentaries. $^{21}$

15 Cf. Bartal, The Jews of Eastern Europe (cf. n. 4), 74; Michael A. Meyer: Response to Modernity. A history of the Reform Movement in Judaism. Detroit/MI 1988, 16; Nancy Sinkoff: Out of the Shtetl. Making Jews Modern in the Polish Borderlands. Providence/RI 2004, 223.

16 Cf. Olga Litvak: Haskalah. The Romantic Movement in Judaism. New Brunswick/NJ-London 2012, 103.

17 Cf. Meyer, Response to Modernity (cf. n. 15), 152; Helmut Teufel: Ein Schüler Mendelssohns. Herz Homberg als jüdischer Propagandist der josephinischen Aufklärung. In: Gerhard Ammerer, Hanns Haas (Ed.): Ambivalenzen der Aufklärung. Festschrift für Ernst Wangerman. Wien-München 1997, 187-204, here 187.

18 Cf. Majer Balaban: Herz Homberg in Galizien. Historische Studie. In: Jahrbuch für jüdische Geschichte und Literatur 19 (1916), 189-221, here 199; Georg Benjamin Mendelssohn: Einleitung in Moses Mendelssohn's Übersetzung der fünf Bücher Mose. In: Idem (Ed.): Moses Mendelssohn's gesammelte Schriften. Vol. 7. Leipzig 1845, XVII-LV, here XXXIX.

19 Cf. Georg Benjamin Mendelssohn: Moses Mendelssohn's Briefe an Herz Homberg. In: Idem (Ed.): Moses Mendelssohn‘s gesammelte Schriften. Vol. 5. Leipzig 1844, 653-655, here 653.

20 Cf. Balaban, Herz Homberg in Galizien (cf. n. 18), 199; Kurt Schubert: Die Geschichte des österreichischen Judentums. Wien 2008, 68; Teufel, Ein Schüler Mendelssohns (cf. n. 17), 188.

21 Cf. Mendelssohn, Einleitung (cf. n. 18), XXXIXf. 


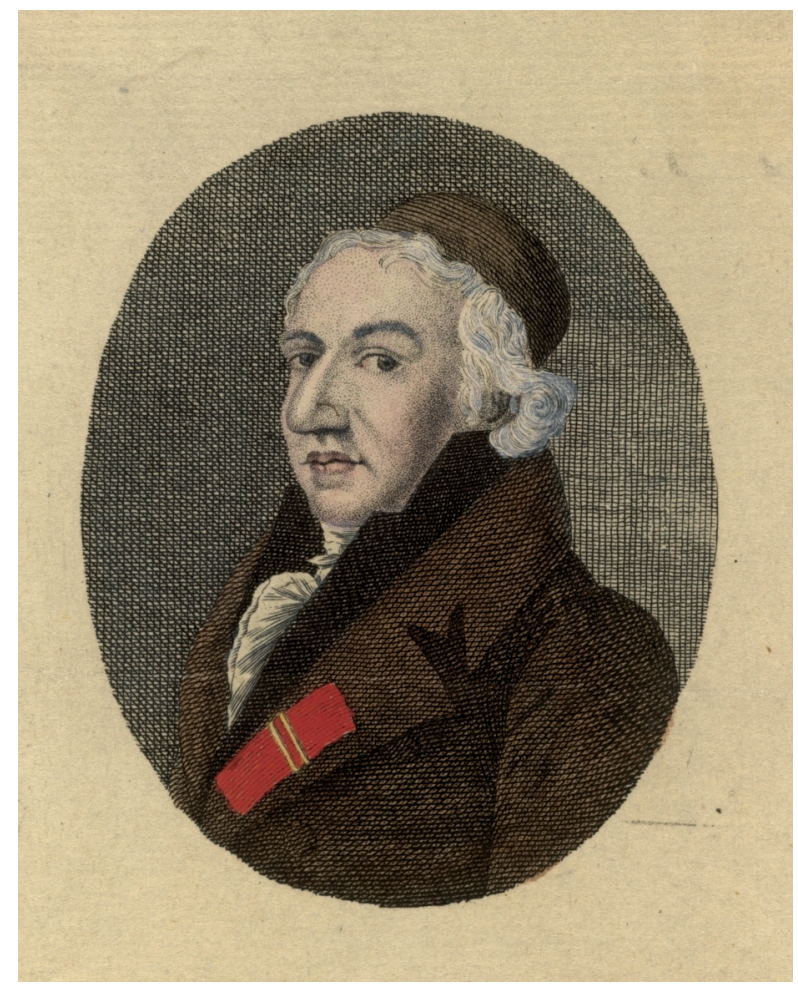

Fig. 1: Portrait of Herz Homberg (Österreichische Nationalbibliothek. Porträtsammlung. Inv.-Nr. PORT_00137939_01).

After the Edict of Tolerance was announced, Homberg moved back to the Habsburg Empire, to Vienna. He initially taught in a Jewish school in the port city of Triest (Trieste), then became the first Jew in Austria to pass the teachers' examination in philosophy and began to lecture at the University of Prague. However, when he applied to become a professor, he was turned down by the Emperor for being Jewish. ${ }^{22}$ Despite this, he did not lose his faith in Joseph II and his reforms. When German schools were to be introduced into the Jewish communities in the Austrian territories, there was hardly anyone more qualified than Homberg to organize these establishments. Galicia, which was annexed by the Habsburg monarchy in the 1772 Partition of Poland, was of special interest because of its considerable Jewish population which, at the time, was the continent's largest. With Galicia's annexation, the Empire's Jewish population doubled to around 400,000. ${ }^{23}$ Moses Mendelssohn himself

22 Cf. Balaban, Herz Homberg in Galizien (cf. n. 18), 200.

23 Cf. Joshua Shanes: Diaspora Nationalism and Jewish Identity in Habsburg Galicia. Cambridge 2012, 20; Sinkoff, Out of the Shtetl (cf. n. 15), $227 \mathrm{f}$. 
recommended that Homberg be appointed in $1787^{24}$ - according to other sources, in $1784^{25}$ - to be the superintendent of the German-Jewish language schools in Galicia and assistant censor of Jewish books. In the same year, Homberg moved to the Galician capital of Lemberg (L'viv, Lwów). In his new role he founded 107 schools in the southern Polish territory as well as the Lemberg teachers' seminary, bringing in maskil teachers from Bohemia.

As well as the aforementioned economic considerations, the Austrian court also viewed Jews as potential 'Germanizing agents' in an overwhelmingly Slavic province. ${ }^{26}$ Homberg played along believing that God decided to educate the Jews so they can become a role model for other peoples:

Als Gott sah, daß die Israeliten (so nennt man diese Nation nach ihrem Erzvater Jakob, der auch den Namen Israel führte,) gut, gesittet und tugendhaft blieben, beschloß er, sie von der drückenden Sklaverei zu befreien, und durch weise und nützliche Gesetze zum Muster und Vorbilde für andere Völker auszubilden, d.i. durch neue und gründliche Lehren besser und vollkommener zu machen. ${ }^{27}$

For centuries Galician Jews had lived in isolation according to the norms and laws of halacha. In this context it was rabbis, community elders and lay judges who executed authority. With the exception of Yiddish and some basic mathematical calculations, schools provided solely religious education. Analphabetism was practically non-existent, although most Jews could write in Hebrew only. When Mendelssohn's German translation of the Torah was first printed, it was burned in public in Kasimir (Kazimierz in Kraków). Here the traditional Jews' fear of the Haskalah managed to unite the competing Hassidic and Mitnagdic streams of Judaism. No wonder that Homberg's arrival was met with skepticism by local Jews. As Nancy Sinkoff explains, "Homberg embodied the state's modernizing bureaucracy: he was cleanshaven, university-educated, and critical of local privilege that was an obstacle to centralization." 28 Because of his 'modern' appearance - most notably, his wig and culottes and his high German pronunciation - the Galician Jews were reluctant to let him lodge in their houses in the ghetto, even though the Austrian authorities insisted that he lived there - Jews were not permitted to live outside of the ghetto. Homberg believed he was on a 'cleansing mission' which did not do anything to make him more accepted in the eyes of the

24 Cf. Balaban, Homberg in Galizien (cf. n. 18), 196; Schubert, Geschichte des österreichischen Judentums (cf. n. 20), 69.

25 Cf. Mendelssohn, Moses Mendelssohn's Briefe an Herz Homberg (cf. n. 19), 654; Teufel, Ein Schüler Mendelssohns (cf. n. 17), $188 \mathrm{f}$.

26 Cf. Balaban, Homberg in Galizien (cf. n. 18), 190 -194, 200; William O. McCagg Jr.: The History of Habsburg Jews, 1670 - 1919. Bloomington-Indianapolis/IN 1989, 111; Shanes, Diaspora Nationalism and Jewish Identity (cf. n. 23), 22; Sinkoff, Out of the Shtetl (cf. n. 15), 223.

27 Naftali Herz Homberg: Bne-Zion. Ein religiös-moralisches Lehrbuch für die Jugend israelitischer Nation. Augsburg 1812, 48 (available online at Bayerische Staatsbibliothek: URL: http://mdz-nbn-re solving.de/urn:nbn:de:bvb:12-bsb11254771-6 [03.03.2020]).

28 Sinkoff, Out of the Shtetl (cf. n. 15), 223. 
locals. However, he did not mind his unpopularity and saw to it that the Police enforced the attendance of the Jewish children at his schools. ${ }^{29}$ One could also compare Homberg's - or, rather, the Austrian state's - activities in Galicia to those Western colonizers who did not simply govern over indigenous peoples, whom they perceived as backward, but also attempted to 'Westernize' them. This 'civilizing mission' was a rationale for Western interventions and colonization from the fifteenth through to the twentieth century. This led Jonathan M. Hess to regard the German states' attempts to 'civilize' Jews as being those of "internal colonization", which functioned "symbolically as a form of surrogate colonialism." 30

Next to his role as a 'civilizer', Homberg was also collecting the so-called candle tax that required married Jewish women to pay a weekly fee for candles. He was eventually charged by the Galician Jews of misappropriating the tax funds, and in 1802 left the Polish territories, returning to Vienna. ${ }^{31}$ According to another source Homberg was recalled in 1806 by Joseph II's nephew, Emperor Francis I, who believed that the Jewish educator might have been a French spy for circulating a pamphlet against the Grand Sanhedrin, a new Jewish high court convened by Napoleon. ${ }^{32}$ According to a third source, Homberg fled to Vienna after the upheaval following the accusations of tax fraud and there he was suspected by the authorities to be a French spy. ${ }^{33}$ Either way, Homberg never returned to Galicia.

Homberg submitted the German translation of a Hebrew-language manuscript to the Court Study and Revision Commission for teaching moral principles in Jewish German schools in 1796. Following years of internal discussions, the commission decided, in 1807 , to commission Homberg to be author of a textbook on religious morality. All agreed that Homberg was the right person to execute the state requirement of elevating the Jews' Bildung. However, they required him to write a new monograph in German and to omit any particulars of the Jewish religion. The result was Bne-Zion, ein religiös-moralisches Lehrbuch für die Jugend israelitischer Nation which was, as Rachel Manekin remarks, similar in its subjects and approach to the general structure of other Austrian catechisms. Bne-Zion was introduced in 1811 in the schools of Galicia, and published in 1812 in Augsburg and Vienna. The two copies were identical but the Augsburg edition presented the author as "Herz Homberg, einem Schüler Mendelssohns", while the Vienna variant omitted the author's name on the title page and said instead: "Mit sr. kais. Königl. Apost. Majestät allergnädigster Druckfreyheit". The commission recognized Homberg's unpopularity among Galician Jews and decid-

29 Cf. Balaban, Homberg in Galizien (cf. n. 18), 190 -194, 200; McCagg, The History of Habsburg Jews (cf. n. 26), 111.

30 Hess, Germans, Jews (cf. n. 9), 44.

31 Cf. Sinkoff, Out of the Shtetl (cf. n. 15), 224.

32 Cf. McCagg, The History of Habsburg Jews (cf. n. 26), 111.

33 Cf. Balaban, Homberg in Galizien (cf. n. 18), 213. 
ed to omit his name. ${ }^{34}$ Homberg's textbook was a compulsory element of the Jewish schools' curricula in the Empire and, for instance, after 1813 prospective brides and grooms were required to pass an examination in the book before receiving a marriage license. ${ }^{35}$ This was difficult for many Galician Jews who could not speak German and were not able to read Homberg's Bne-Zion. Consequently most of them decided not to be married by the civil registrar, but only by rabbis, even though this was no longer accepted by the Austrian authorities. ${ }^{36}$ Nonetheless, the caveat remained in the book until 1918. ${ }^{37}$

Homberg's career is a great example of individual mobility, that is, of an individual's ability to move from a lower-status group to a higher-status one. Homberg came from a traditional Jewish family without any knowledge of German and ended up as one of the Austrian court's most trusted Jewish educators. But, as social psychologists Henri Tajfel and John Turner underline, individual mobility does not change social hierarchies and, despite their efforts, those who experience such mobility can also be affected by the prejudices their group of origin faces. Moreover, they are often perceived by the rest of their group of origin to be 'traitors' for disassociating themselves from their original social status. ${ }^{38}$ This was certainly true for Homberg who suffered not only from structural discrimination but became the subject of anti-Jewish conspiracy theories - and of continuous intra-Jewish critiques both during and after his life.

Homberg's life and works have been discussed by several Jewish studies scholars, for example by Israel Bartal, Michael A. Meyer or Nancy Sinkoff who analyzed Homberg within a framework of early modern (Eastern-)European Jewry and the Haskalah. I will also refer to scholars of Eastern European Jewry Rachel Manekin and Helmut Teufel, and their publications on Bne-Zion. Coming from the social sciences, I intend to add a new perspective to the Homberg bibliography with an emphasis on intergroup relations between the Jewish minority and the non-Jewish majority. I will look into the German Enlightenment and the Austrian Empire's assimilationist policies and try to show how these were internalized by Homberg. In order to illustrate this I will draw on the reproduction of these ideals in Homberg's Bne-Zion.

34 Cf. Manekin, The Moral Education (cf. n. 13), 273, 282-284, 289; Schubert, Geschichte des österreichischen Judentums (cf. n. 20), 67.

35 Cf. Hillel J. Kieval: Languages of Community. The Jewish Experience in the Czech lands. BerkeleyLos Angeles/CA-London 2000, 60.

36 Cf. Balaban, Homberg in Galizien (cf. n. 18), $216 \mathrm{f}$.

37 Cf. Sinkoff, Out of the Shtetl (cf. n. 15), 224.

38 Cf. Henri Tajfel, John C. Turner: The Social Identity Theory of Intergroup Behavior. In: William G. Austin, Stephen Worchel (Ed.): Psychology of Intergroup Relations. Chicago/IL 1986, 7-24, here $8-10$. 


\section{A Jew for the Emperor and the Empire}

Bne-Zion opens with a decree by the $k$. u. k. ("Imperial and Royal" - referring to Imperial Austria and Royal Hungary's) Court Commission on Education from 1810. The decree stated that the Emperor was interested in the welfare of its subjects, but without "gute Sitten" this was not possible. To achieve this, the Emperor ordered the publication of a religious-moral reader for Jews in the territories of the Austrian crown. He emphasized that these teachings were not only results of rational thinking, but also derived from "den heiligen Büchern der Israeliten". The decree stated that the Emperor was content with the work and ordered that the book be used in all Jewish schools of the "deutschen Erbstaaten" as a state-required teaching material. In addition, according to the order, all brides and grooms were to be examined by authorities based on this reader. ${ }^{39}$ The book also includes a two-page-long approbation from 1810 by Moravian chief rabbi Marcus Benedikt, also known as Mordecai Benet. The Hungarian-born rabbi was a declared traditionalist, so Helmut Teufel wonders why he recommended Homberg's book. ${ }^{40}$ I believe that this is because Benedikt tried to prevent a full-fledged break with non-Orthodox Jews. ${ }^{41}$

Homberg's Bne-Zion fulfilled royal expectations. This is not surprising knowing that, as Nancy Sinkoff wrote, "[u]ncritical support of Habsburg cameralism distinguished Homberg's worldview." " 22 Helmut Teufel characterized Homberg simply as "jüdischer Propagandist der josephinischen Aufklärung." 43 In my opinion, we might argue that Homberg can be regarded as a 'native informant'. As Gayatri Chakravorty Spivak suggested, a native informant's role is to provide information on their group of origin, but they are also exploited in order to consolidate Western theories, since Westerners "take for granted that the 'European' is the human norm and offer us descriptions and/or prescriptions." Spivak also noted that "there is the self-marginalizing and self-consolidating migrant or postcolonial masquerading as "native informant'." 44 Just like native informants today, Homberg also profited from his native informant status in his role as assistant censor of Jewish books. In memoranda and government conferences, he proposed the prohibition of several Jewish books including that of the traditional prayer book, seeing that it contained prayers for the end of

39 Homberg, Bne-Zion (cf. n. 27), if.

40 Cf. Teufel, Ein Schüler Mendelssohns (cf. n. 17), 190 f.

41 Cf. Adam S. Ferziger: Mordekhai ben Avraham Banet. In: YIVO Encyclopedia of Jews in Eastern Europe (02.06.2010). URL: https://yivoencyclopedia.org/article.aspx/Banet_Mordekhai_ben_Avra ham (24.02.2020); Manekin, The Moral Education (cf. n. 13), 273.

42 Sinkoff, Out of the Shtetl (cf. n. 15), 223.

43 Teufel, Ein Schüler Mendelssohns (cf. n. 17), 187.

44 Gayatri Chakravorty Spivak: A Critique of Postcolonial Reason. Towards a History of the Vanishing Present. Cambridge/MA 1999, 6. 


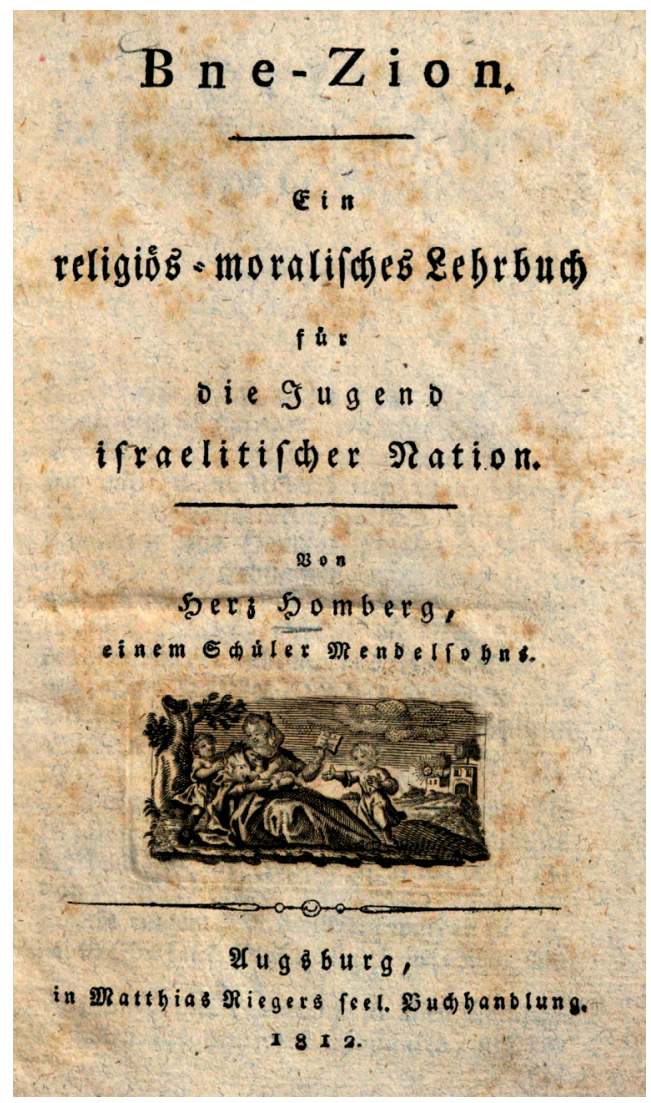

Fig. 2: Titlepage of Homberg's Bne Zion (Staats- und Stadtbibliothek Augsburg, Jud 245, http://mdznbn-resolving.de/urn:nbn:de:bvb:12-bsb11254771-6).

the Jews' exile and their return to the Holy Land. These messianic aspirations were not compatible with Homberg's loyalty to the throne. ${ }^{45}$

Homberg blamed the rabbinate for this situation, which he wished to replace with modern Jewish educators who would completely re-educate the 'backward' Jews, even if it be against their will. Other maskilim also shared anti-rabbinic sentiments and preferred 'preachers' to be leaders of the Jewish religious community who did not perform the ritual tasks like traditional rabbis. ${ }^{46}$ No wonder that in Homberg's list of teachers who educate in matters of religion, rabbis come last after school teachers, nursery teachers, headmasters and college teachers. ${ }^{47}$ Homberg feared that Jews would rather obey rabbis and the Jewish law than sovereigns and

45 Cf. Meyer, Response to Modernity (cf. n. 15), 152; Sinkoff, Out of the Shtetl (cf. n. 15), 223.

46 Cf. Meyer, Response to Modernity (cf. n. 15), 100.

47 Cf. Homberg, Bne-Zion (cf. n. 27), 164. 
their legislative power. This fear was shared by other enlightened non-Jewish thinkers and statesmen too. In 1785, Joseph II abolished rabbinical courts and the rabbis' authority to adjudicate civil cases among Jews, and deprived the communities of their juridical powers. ${ }^{48}$ Restrictions of rabbinical autonomy were also made in other German-speaking territories, for example in Mainz, where the Prince-Elector's 1784 order made rabbis present their school syllabi for approval. ${ }^{49}$ Homberg repeatedly highlighted the importance of Jewish loyalty to the sovereign which we can also understand as a manifestation of his role as a native informant:

Aus diesem [...] allgemein angenommenen Lehrsatze folget, daß wir Israeliten verpflichtet sind, den Landesgesetzen christlicher Regenten strengen Gehorsam zu leisten; weil sie uns in dem nämlichen Grade verbinden, als ob sie israelitische Staatsgesetze wären. Es folgt daraus, daß wir die bürgerliche Verfassung, in welcher wir leben, hochschätzen, ihre Unterordnungen willig befolgen, die christliche Obrigkeit, Räthe, Richter und Beamten so verehren sollen, als wenn sie israelitische Vorgesetzte wären. ${ }^{50}$

Jewish demonstration of support for non-Jewish rulers has been around for over a millennium, but it became especially relevant in the Haskalah period, Moses Mendelssohn himself expressed his devout Prussian patriotism in his writings. ${ }^{51}$ In Bne-Zion, Homberg compared the Austrian royals to God on several occasions. For example, while discussing the prohibition of uttering God's name in vain, he compared it to respect for the wordily sovereign and stated that they are not called by their names either, but by their title. ${ }^{52}$ Furthermore, he wrote that the highest temporal power was a reflection of spiritual power; and one should follow the human rulers and act according to their (wordily) orders, just like one looks up to God and God's (religious) commandments. Besides this comparison, Homberg claimed that sovereigns were instituted by God to lead people according to divine will with justice, tolerance and love, and to foster happiness in society. ${ }^{53}$ Homberg encouraged Jews to pray for their non-Jewish sovereigns, referring to Jeremiah 29:7 ("Seek the peace and prosperity of the city where I lead you to in exile, and pray to the Lord for it, for the city's peace is your peace"):

Es ist daher unsre Schuldigkeit, für das Wohlergehen des Landesfürsten, seines Hauses, seiner Minister und Räthe fleißig zu Gott zu bethen, und von ihm Ruhe, Sicherheit und Wohlfahrt des Staates zu erflehen. [...] Unsere Rabbinen haben daher verordnet, am Sabbathe und an Feiertagen in den Synagogen folgendes Gebeth zu verrichten: O Gott! Der du den Königen dein Heil,

48 Cf. Hieronymus von Scari: Systematische Darstellung der in Betreff der Juden in Mähren und im k. k. Antheile Schlesiens erlassenen Gesetze und Verordnungen. Brünn 1835, 160; Balaban, Homberg in Galizien (cf. n. 18), 195.

49 Cf. Eliav, Jüdische Erziehung in Deutschland (cf. n. 2), 236.

50 Homberg, Bne-Zion (cf. n. 27), 177.

51 Cf. Meyer, Response to Modernity (cf. n. 15), 34, 59.

52 Cf. Homberg, Bne-Zion (cf. n. 27), 71f.

53 Cf. ibid., 175, $179 \mathrm{f}$. 
den Fürsten Herrschergewalt verleihest [...], behüte und bewahre, erhöhe und segne unsern Landesherrn (oder Landesfrau). 0, König aller Könige! Erhalte ihn (sie) lange beim höchsten Wohlsein; behüte ihn (sie) vor Schaden, Kummer und Trübsal; erhebe den Glanz seiner (ihrer) Krone, daß Völker seiner (ihrer) Leitung sich willig unterwerfen; die Feinde aber zu seinen (ihren) Füßen hinstürzen. ${ }^{54}$

Reading Jeremiah 29:7 as a source of Jewish support for the sovereign was common among nineteenth-century Jewish intellectuals and rabbis in German-speaking countries and beyond. ${ }^{55}$ However, it was not only the sovereign to whom Jews pledged allegiance, but also their respective countries of residence. Homberg emphasized that Jews have to be loyal to the leader and mean it seriously when say "Vaterland". He compared this loyalty to that of Biblical figure Mordechai, who saved the Jewish people from extinction through his work in Persian King Achashverosh's court. ${ }^{56}$ Homberg also justified armed conflict when the "Vaterland" is attacked by enemies. ${ }^{57}$ He frequently used the term "Vaterland", which has no historic Hebrew equivalent, ${ }^{58}$ but was first used with reference to individual German states. Homberg explained "Vaterland" as the state of all those who were born and raised there, and also of those who settled down in the country and enjoyed all its rights and duties. ${ }^{59}$ If necessary, one has to defend the home country by the sword:

Wir sollen unser Vaterland lieben, d. i. seine Verfassung, Gesetze, Einrichtung, Sitten und Gebräuche über alle andere hochschätzen [...]. Daher sollen auch Diejenigen, welche aufgefordert warden, das Vaterland gegen feindliche Angriffe zu vertheidigen, diese große Pflicht willig übernehmen und getreu erfüllen. [...] Man kann aus dieser Welt auf keine edlere Art scheiden, als durch den Heldentod im Gefecht für Mitbürger und gesetzliche Freyheit. ${ }^{60}$

For Homberg, however, being ready to sacrifice one's life for the "Vaterland" was not sufficient. He demanded that soldiers obey their superiors without any second thought - even if they did not understand the point of the orders - and be satisfied with the salary. The soldier's understanding was considered too limited to fully comprehend the necessity of all the orders passed down by the authorities. ${ }^{61}$ Homberg did not challenge the - to use the Marxist term - "reproduction of the relations of production" of his time. ${ }^{62}$ Rather, he reassured servants in their servant-ness and

54 Ibid, $180 \mathrm{f}$.

55 Cf. Michael Brenner, Stefi Jersch-Wenzel, Michael A. Meyer: Deutsch-jüdische Geschichte in der Neuzeit. Vol. 2: Emanzipation und Akkulturation 1780 -1871. München 2000, 268; Langer, Vergeblich integriert? (cf. n. 7), 49.

56 Cf. Homberg, Bne-Zion (cf. n. 27), $181 \mathrm{f}$.

57 Cf. ibid., 148.

58 Cf. Langer, Vergeblich integriert? (cf. n. 7), 61.

59 Cf. Homberg, Bne-Zion (cf. n. 27), 171.

60 Ibid., $175 f$.

61 Cf. ibid., $176 \mathrm{f}$.

62 Althusser, On the Reproduction of Capitalism (cf. n. 14), 3. 
masters in their master-ness; encouraged the rich to enjoy their richness, and recommended the poor not to envy the rich but rather to trust in God. ${ }^{63}$

Homberg also proved his patriotism in the treatise on special relationships between humans. In his list of people with whom one has close relationships, Homberg did not only list relatives but also fellow citizens. ${ }^{64}$ One is obliged to love them like members of one's own family, according to Homberg. To express the Jews' belonging to the national collective, he refrained from using the terms "Jude" or "jüdisch", instead preferring the words "Israelit" and "israelitisch" throughout his work. At the time "Israelite" was preferred to accentuate the idea that Judaism was not an ethnicity or nationality, but rather a confession within German nationhood. "Israelite”, and other new self-designations like "Mosaist”, was meant to underline Judaism's compatibility with Germanness. ${ }^{65}$ In the words of nineteenth-century liberal Jewish leader Levi Lazar Hellwitz: "Der Israelit ist nicht mehr Mitglied einer israelischen Nation, sondern nur eines israelitischen Glaubens.”66

\section{The Germanization of Judaism}

The 1782 Edict of Tolerance granted Jews in Lower Austria, and later in other provinces of the Empire, civil rights for the first time in their history. However, this edict had several restrictions, especially regarding the Jews' status as ethnic and religious minority in the multi-ethnic and multi-religious Habsburg empire. The edict decreed that Jews would not be allowed to worship in public or to establish their own press for the printing of prayer books and other Hebrew publications. If they wished to import Jewish books from abroad, which was in general forbidden, they were obligated to apply for permission and submit imported books to the censor. Moreover, the edict prohibited the public usage of Hebrew and Yiddish ("die [...] hebräisch mit deutsch vermengte, sogenannte jüdische Sprache”) 'to maintain common confidence'. ${ }^{67}$ This prohibition also affected schools, including those in Galicia after the edict was extended in 1789 to the former Polish kingdom. ${ }^{68}$

However, none of these reforms served the Jews' integration. As social psychologist John Berry explains, one can speak of integration only if mutual accommodation is present; if both dominant and non-dominant groups accept the right of everyone to

63 Cf. Homberg, Bne-Zion (cf. n. 27), 166-168.

64 Cf. ibid., 156.

65 Cf. Michael A. Meyer: The Origins of the Modern Jew. Jewish Identity and European Culture in Germany, 1749-1824. Detroit/MI 1972, 127, 152, 197; Meyer, Response to Modernity (cf. n. 15), 30.

66 L. L. Hellwitz: Der Organisation der Israeliten in Deutschland. Magdeburg 1819, 62. According to Michael A. Meyer, Hellwitz is not the real author of the book where this quote is from, but historian Leopold Zunz. See Meyer, The Origins (cf. n. 65), 214.

67 Toleranzpatent (cf. n. 3), 278.

68 Cf. Sinkoff, Out of the Shtetl (cf. n. 15), 220. 
live as culturally different peoples. Integration requires the minorities to adopt the values of the majority, while at the same time requiring the majority to be prepared to adapt national institutions to meet the needs of all groups living together in a plural society. ${ }^{69}$ However, instead of integrating expressions of Jewish cultural and religious identity into Austrian society, the Josephinian reforms promoted Jewish assimilation and their 'Germanization'. Education was the gateway to the Jews' 'integration' into enlightened society. In his attempt to affirm the importance of education, Homberg explained that the eagerness to learn belongs to the natural characteristics of the soul $^{70}$ and highlighted the state's role in supporting this:

Auch muß der Staat Sorge tragen, die jungen Bürger und Bürgerinnen in der Religion, Moral und andern nützlichen Kenntnissen gehörig unterrichten zu lassen, und deshalb Schulen anzulegen; für Künste und Wissenschaften aber, als Gottesgelehrtheit, Weltweisheit, Naturlehre, Meßkunde, Mechanik, Baukunst, Rechtgelehrsamkeit, Arzneiwissenschaften, Geschichte, Geographie, Länderkunde u. a. mehr wissenswürdige Gegenstände in den Hauptstädten hohe Schulen zu errichten und Lehrer von geprüfter Geschicklichkeit [...] zu ernennen. ${ }^{71}$

Homberg called the child's first responsibility to pay attention to teachers, parents and "vernünftigen Personen", because only a person engaging in serious learning can acquire ways of rational thinking. The sooner one reaches the level of Vernunft, the clearer and brighter one will understand God's words and will. ${ }^{72}$ Rational thinking is inherently connected to religiosity and leads to the religion of reason, to the Kantian Vernunftreligion. For Homberg, the need to strive for higher knowledge and arrange one's life following rational thinking (Vernunft) was the reason for human existence. ${ }^{73}$ In his commitment to promoting this Vernunftreligion, Homberg repeated several times that God cannot have a body. For instance, in his exposition on the prohibition of graven images, he indicated that God disliked being perceived as a bodily being. ${ }^{74}$ Once more this is a statement in complete accordance with Kant, who praised the Biblical prohibition of images: "Vielleicht gibt es keine erhabenere Stelle im Gesetzbuche der Juden, als das Gebot: Du sollst dir kein Bildnis machen [...]. Eben dasselbe gilt auch von der Vorstellung des moralischen Gesetzes und der Anlage zur Moralität in uns."75

69 Cf. Berry, Immigration, Acculturation, and Adaptation (cf. n. 6), $10 \mathrm{f}$.

70 Cf. Homberg, Bne-Zion (cf. n. 27), 8.

71 Ibid.,173.

72 Cf. ibid., $93 \mathrm{f}$.

73 Cf. ibid., 11.

74 Cf. ibid., 60.

75 Immanuel Kant: Kritik der Urteilskraft. In: Idem: Werke in zehn Bänden. Ed. by Wilhelm Weischedel. Vol. 8: Kritik der Urteilskraft und Schriften zur Naturphilosophie. Sonderausgabe. Darmstadt 1983, 233-620, here 365. 
Homberg's philosophy of religion can be summarized in the following sentence: "Gott durch das Licht der Vernunft erkennen."76 He believed that by observing nature and its changes one could not arrive at a different logical conclusion than faith, and anything that would obscure this Licht der Vernunft, such as superstitions, was to be censored. ${ }^{77}$ Indeed, superstitions are prohibited by normative Judaism. However, Homberg's long essay against superstition might have been a reaction to the new, charismatic (Hassidic) Jewish streams which put a focus on mysticism, especially the kabbalah. Many of these Hassidic sects originated in Hungarian and Polish territories which belonged to the Austrian Empire. As censor Homberg put several Kabbalistic works on his list of prohibited books. ${ }^{78}$

The process of the Jews' 'Germanization' did not only affect the Jews' education, but also their contribution to the state's economic development. Homberg put an emphasis on labour. He argued that Jews do not receive 'manna from heaven' anymore, that the Talmudic sages were working themselves and that one should not feel ashamed of working. ${ }^{79}$ This commitment to employment can also be interpreted as a reaction to the anti-Jewish stereotype of Jews not doing 'proper work', but rather being engaged as merchants and peddlers. Homberg claimed that many young Jewish men chose this path since they wanted to become instantly rich ${ }^{80}$ He spoke of them with great pity. They were, according to him, not investing their youthful energies in useful work, but rather carrying around old worn clothes and selling their sad products with much noise. Homberg warned that the high percentage of Jews amongst the merchant class would awake anti-Jewish stereotypes:

Dieser herrschende Hang zum Handeln, und besonders das unselige Hausiren, hat unsere Nation in den sehr nachtheiligen Verdacht gebracht, als ob es ihr an gutem Willen fehle, sich auf anderen Wegen außer der Handlung dem Staate nützlich zu machen. Jeder Verdacht [...] schadet, so lang er nicht widerlegt wird. Es ist also unsere Pflicht, denselben dadurch zu vernichten, daß viele junge Leute sich dem Ackerbaue, der Landwirtschaft, der Gärtnerei und dergleichen wiedmen $\left[\ldots . .{ }^{81}\right.$

Homberg also mentioned another anti-Jewish stereotype, namely that Jews would demand higher interests than allowed. He condemned these speculators and wrote that the only thing that makes the usurer different from a thief is that the former is nonviolent. ${ }^{82}$ At the same time, he neglected to recount anti-Jewish laws which had prohibited Jews to practice physical labour for centuries. European states did not allow

76 Homberg, Bne-Zion (cf. n. 27), 25.

77 Cf. ibid., 65.

78 Cf. Sinkoff, Out of the Shtetl (cf. n. 15), 223.

79 Cf. Homberg, Bne-Zion (cf. n. 27), 101f., $127 \mathrm{f}$.

80 Cf. ibid., $128 \mathrm{f}$.

81 Ibid., 132.

82 Cf. ibid., $133 \mathrm{f}$. 
many employment opportunities for Jews other than to be involved in trade. ${ }^{83}$ Even though Homberg made a short reference to legal hurdles, he asserted that these times were gone, especially in Austria, where a mild government let Jews earn their daily bread in different ways. ${ }^{84}$ His silence on structural discrimination is especially visible in the chapter on the citizens' rights and duties. So despite his detailed treatise on human dignity and equality, he failed to note that in the European empires of his time, including in Austria, not all citizens were equal; and not all humans were citizens. He spoke about the importance of judges but did not mention that only Christian men were appointed to this position. He praised the royal army officers but did not acknowledge that Jews could not become army officers; this was first allowed in Austria-Hungary in 1867. He described the hierarchy of the state officials without explaining that Jews had to convert if they wanted to be clerks or other state representatives. This is particularly disappointing given that Homberg had his application to become a professor turned down on account of his Jewishness. The only discriminatory measures he mentioned were the special taxes Jews had to pay in feudal societies, and even then he did not question their legitimacy. On the contrary, he pointed to that part of the Talmud which demanded Jews pay their taxes. ${ }^{85}$

Homberg blamed the Jews above everyone else for their own oppression, and did not address the authorities' role in it. One could speak in Homberg's case of 'victimblaming' which occurs when victims of a wrongful act are held responsible for the harm that befell them. The ideology of blaming the victim - according to social psychologist William Ryan - is a "systematically motivated, but unintended" distortion of reality which is "rooted in a class-based interest in maintaining the status quo". Ryan held that the so-called victim-blamers are essentializing the minorities in question instead of looking at the core of the problem which is, according Ryan, economic inequality. ${ }^{86}$ In particular those who believe in a just society, where people get what they deserve and deserve what they get, tend to blame the victims in order to protect their belief that the world is a just place. ${ }^{87}$

83 Cf. Nina Rowe: The Jew, the Cathedral, and the Medieval City. Synagoga and Ecclesia in the Thirteenth Century. Cambridge 2011, 35.

84 Cf. Homberg, Bne-Zion (cf. n. 27), 135.

85 Cf. ibid., $178 \mathrm{f}$.

86 William Ryan: Blaming the Victim. New York 1976, 11.

87 Cf. Lauren D. Appelbaum, Mary Clare Lennon, J. Lawrence Aber: When Effort is Threatening. The Influence of the Belief in a Just World on Americans' Attitudes toward Antipoverty Policy. In: Political Psychology 27/3 (2006), 387-402, here $390 \mathrm{f}$. 


\section{The Christianization of Judaism}

In the Age of Emancipation, becoming German did not only affect the realms of education, employment and national identity, but also the realm of religion. Liberal Judaism, which emerged from the Haskalah, was heavily oriented around Christian role models. Newly built synagogues were constructed along the lines of Christian churches. Moreover, they were called Tempel, since those who attended were no longer praying for the rebuilding of the Jerusalem Temple and the return to Zion, because the German states were now regarded as their Zion. German became the language of the liturgy, and prayer-books were now read from left to right. Congregants no longer wore black skullcaps, coming to temple bareheaded. Rabbis dressed in priest-like robes and held sermons that followed the structure of Schleiermacher's homiletic teachings. Instead of the traditional Jewish coming-of-age ceremonies of bar mitzvah and bat mitzvah, Reform temples introduced confirmation for children. Protestant Christianity was regarded as an example not only in an aesthetic, but also in a theological and ideological sense. ${ }^{88}$ This is manifested, for example, in a Liberal Jewish critique and through the abandonment of the Talmud, which had been a target of Christian polemics since the early Middle Ages. According to this critique, the backwardness of the Jews was mainly due to their alleged abandonment of the Bible and stubborn insistence on the Talmud. Several maskilim - such as historian Heinrich Graetz or liberal rabbis Zacharias Frankel and Abraham Geiger - doubted the divine nature of the Talmud and omitted references to rabbinical literature. Rabbis who espoused radical reform, such as Samuel Holdheim, denied all authority to the Talmud. ${ }^{89}$

Homberg was also affected by this anti-Talmudic tendency. For instance, the Talmud was condemned as "un-enlightened" and "un-European" in the Lemberg teachers' seminary. ${ }^{90}$ In Bne-Zion, too, there is an emphasis on the Hebrew Bible to the cost of rabbinical literature. According to my calculations he quoted from the Torah 83 times and from the Psalms 48 times. Other Biblical sources included the prophets - such as Isaiah (10), Jeremiah (5) and Ezekiel (2) - and other texts such as Proverbs (28), Ecclesiastes (7) and Daniel (2). The books of Isaiah and Jeremiah were especially popular among maskilim for drawing attention to moral teachings above those of ritual observances. So despite the Talmud having equal status to the Bible in normative Judaism, Homberg cited the former only 17 times. Moreover, he did not mention specific tractates and chapters when it came to the Talmud, in stark

88 Cf. Brenner/Jersch-Wenzel/Meyer, Deutsch-jüdische Geschichte. Bd. 2 (cf. n. 55), 199; Langer, Vergeblich integriert? (cf. n. 7), 99f.; Meyer, Response to Modernity (cf. n. 15), 129.

89 Cf. Langer, Vergeblich integriert? (cf. n. 7), 101; Michael A. Meyer: “Scripture or Spirit?”: The Revelation Question in German-Jewish Thought of the Nineteenth Century. In: Idem: Judaism within Modernity. Essays on Jewish History and Religion. Detroit/MI 2001, 111-126, here 117; Idem, Response to Modernity (cf. n. 15), 81, 113.

90 Cf. Sinkoff, Out of the Shtetl (cf. n. 15), 223. 
contrast to his use of Biblical sources. Homberg also quoted 17 times from the Mishnaic tractate Avot (literally: Fathers), also known as 'Ethics of the Fathers'. The high number of quotes from this short tractate might be because of the ethical focus of the text, Avot is the sole Mishnaic tractate to contain little or no halachic rulings.

Parallel to these practical changes, nineteenth-century Jewish intellectuals who were disturbed by Jewish particularism promoted the reform of Jewish religious philosophy. "Reine Vernunft ist für sich allein praktisch, und gibt (dem Menschen) ein allgemeines Gesetz, welches wir das Sittengesetz nennnen”, wrote Kant, claiming that only that set of laws can be considered a good set of laws, whose laws apply for all. For him a true religion cannot be particularistic. ${ }^{91}$ For this reason, Kant endorsed the abandonment of expressions of Jewish religious identity, such as ritual practices, as an initial step; to be followed by conversion to Christianity at a later time: "Die Euthanasie des Judentums ist die reine moralische Religion, mit Verlassung aller alten Satzungslehren." 92 He taught that the best option for Jews to become useful members of the German society was to publicly accept Jesus and the Gospels. Amid this assimilationist pressure liberal Jewish thinkers, for whom ethics was the heart of Judaism, tried to show that universalism and morality reflected in Jewish tradition did not fall beneath that of Christianity. ${ }^{93}$ Homberg, too, presented Judaism as a universalistic religion that would fit into the enlightened world view. This can be seen in the way that Homberg's book does not mention 'Jews', he preferred 'humans', in any of its chapter titles; even though the work's goal was to educate Jews. He did not discuss how Jews should act according to normative Judaism setting out chapter titles such as "Von dem, was der Mensch gegen sich selbst zu beobachten schuldig ist”, "Von der Abhängigkeit der Menschen von einander, und der daraus entstehenden Pflichten" and "Von den Pflichten des Menschen als Bürger". ${ }^{94}$ This universalism is typical of the whole work, which often reads as a general introduction to ethics rather than a schoolbook for Jewish children.

Homberg also offered a universalistic take on explicitly Jewish topics. For instance, in his explanation of the Shabbat, Homberg did not mention any halachic precepts connected to the day, but interpreted the Shabbat as an opportunity to think about the reason for one's existence. ${ }^{95} \mathrm{He}$ was not the first maskil to 'de-judify' the Shabbat since some radical reformers had even suggested it be moved to a

91 Immanuel Kant: Kritik der praktischen Vernunft. In: Idem: Werke in zehn Bänden. Ed. by Wilhelm Weischedel. Vol. 6: Schriften zur Ethik und Religionsphilosophie. Erster Teil. Sonderausgabe. Darmstadt 1983, 103-302, here 142.

92 Idem, Der Streit der Facultäten. In: Idem: Werke in zehn Bänden. Ed. by Wilhelm Weischedel. Vol. 9: Schriften zur Anthropologie, Geschichtsphilosophie, Politik und Pädagogik. Erster Teil. Sonderausgabe. Darmstadt 1983, 261-393, here 321.

93 Cf. Meyer, Response to Modernity (cf. n. 15), 204.

94 Homberg, Bne-Zion (cf. n. 27), vi.

95 Cf. ibid. $72-75$. 
Sunday. ${ }^{96}$ Homberg emphasized that this day was simply "der wöchentliche Ruhetag”, holy for all educated nations in remembering creation through a total pause of all work. Homberg made the Sabbath a universal holiday encouraging good will towards all creation, especially humans. ${ }^{97} \mathrm{He}$ also considered the ten commandments to be universalistic:

Bei keinem dieser [...] Gebothe findet man die geringste Spur, als ob sie nur gegen Israeliten, nicht aber gegen Menschen von einer anderen Religion und Abkunft beobachtet werden müßten. Die Schrift verbietet Morden, Unzucht treiben und Stehlen, ohne auf die Person zu sehen, an welcher solche oder andere Verbrechen verübt werden. Bei Gott sind alle Menschen gleich; so verschieden sie in ihren Glaubensmeinungen sind..$^{98}$

In terms of the Biblical commandment of 'loving one's neighbour as oneself', Leviticus 19:18, Homberg explained that all humans are the Jews' neighbours, especially those they live with in the same state and under the same laws; even if they may have different religious opinions. In his reading the term "neighbour" ("Nächster") refers to all peoples, religions and colours. He disregarded the centuries-old rabbinic debate on what 'neighbour' and 'love' means. Moreover, when it came to explicitly particularistic laws, Homberg taught that while this kind of separation was necessary in the past, such as in the Mosaic constitution, this was not longer the case. Back then the Israelite nation had to separate itself through its laws from the 'sinful' peoples who lived at that time. ${ }^{99}$ He believed that religious rituals were not applicable anymore and did not observe the halacha - in the spirit of the Kantian "Euthanasie des Judentums". ${ }^{100}$ Indeed, four of Homberg's sons converted to Christianity and thereby realized the second step of the Kantian program. ${ }^{101}$ This was perhaps the major difference between the Hombergian and Mendelssohnian approaches to the Haskalah. Mendelssohn, who remained halachically observant, expressed his critique in a letter to Homberg: "Über die Nothwendigkeit der Ritualgesetze sind wir nicht einerlei Meinung. Wenn auch ihre Bedeutung als Schriftart oder Zeichensprache ihren Nutzen verloren hätte, so hört doch ihre Nothwendigkeit als Band der Vereinigung nicht auf." ${ }^{102}$ Apparently Mendelssohn saw the sociological importance of keeping the religious commandments, and believed that their role was to keep the Jewish people together.

We can also observe a universalistic tendency in Homberg's discussion on JewishChristian relations. Homberg explained that Jews have to love all humans and all peo-

96 Cf. Meyer, Response to Modernity (cf. n. 15), 139.

97 Homberg, Bne-Zion (cf. n. 27), 74.

98 Ibid., 83.

99 Cf. ibid., $87 \mathrm{f}$.

100 Cf. Meyer, Response to Modernity (cf. n. 15), 152.

101 Cf. Teufel, Ein Schüler Mendelssohns (cf. n. 17), 190.

102 Moses Mendelssohn an Herz Homberg. 22.09.1783. In: Georg Benjamin Mendelssohn (Ed.): Moses Mendelssohn's gesammelte Schriften. Vol. 5. Leipzig 1844, 668-670, here 669. 
ples, "so wie unsre Religionsverwandten [...] weil Gott alle Menschen liebt". ${ }^{103}$ This should be especially valid for Christians who, as Homberg maintained, Jews should oppose the least, because many of their core religious principles, such as monotheism and the teaching of loving one's neighbour, are holy for Jews too. ${ }^{104}$ To indicate the similarities between Judaism and Christianity, Homberg used Christian language to describe Jewish scriptures. He restrained from using the Hebrew word 'Torah', and used 'German/Christian' names for the Mosaic books ("1 Moses”, "2 Moses”, etc.) instead of the 'Hebrew/Jewish' terminologies ('Breshit', 'Shmot', etc.). Homberg did the same in the case of other Biblical books. For instance, he referred to the book of 'Kohelet' as "Pred. Salom." (Predigten Salomons); and referred to the Hebrew Bible - known among Jews as the 'Tanach' which is an abbreviation for Torah (Ta), Prophets (Na) and other writings (Ch) - as "heilige Schrift", "Schrift" or simply "Bibel". While these names for the Hebrew Bible are not incorrect, they can be described as a Christian-influenced terminology. ${ }^{105}$

\section{Assimilation in vain? Homberg and the Jews in the German-speaking territories}

Despite Homberg's commitment to the cause of the Josephinian reforms and the Enlightenment, his legacy is ambivalent. As Israel Bartal wrote, "Homberg played a Janus-faced role: he represented the intentions of the government to 'civilize' the 'native' population, the same population of which he was part, although he had moved into a new Jewish cultural elite". ${ }^{106}$ The Galician Jews did not trust Homberg's schools and the Austrian authorities did not derive any satisfaction either. By 1806 the schools that had been established by Homberg in Galicia were more or less all dysfunctional as Jewish schools and were eventually closed by imperial decree. Despite the authority's measures, local Jews refused to send their children to Homberg's school. The Emperor even published announcements in Galician synagogues expressing dissatisfaction with the community and Homberg's schools were eventually integrated into the federal school system. ${ }^{107}$ Homberg returned to work as a censor and an author in Vienna until 1814, when he moved back to Prague after his residence permit for Austria was not extended. After that he initially tried to establish an 'enlightened' rabbinical seminary in Prague. However, this failed due to resistance from the local Jewish community. ${ }^{108}$ In 1818, he was assigned to be an instructor in

103 Homberg, Bne-Zion (cf. n. 27), 143.

104 Cf. ibid., 142-145.

105 Ibid., 50, 68, 72, 100, etc.

106 Bartal, The Jews of Eastern Europe (cf. n. 4), 75.

107 Cf. ibid., 75f.; Balaban, Homberg in Galizien (cf. n. 18), 201f.; Teufel, Ein Schüler Mendelssohns (cf. n. 17), 189.

108 Cf. Teufel, Ein Schüler Mendelssohns (cf. n. 17), 190. 
religious ethics for students attending gymnasiums in Prague, where he also worked as a Jewish private tutor. His appointment was, according to Hillel J. Kieval, "a sure indication of the breadth of Enlightenment indoctrination in the capital". ${ }^{109} \mathrm{Hom}$ berg served in this function till his death in $1841{ }^{110}$

In his 1783 letter to Herz Homberg, Moses Mendelssohn warned the Austro-Bohemian educator and writer of being too enthusiastic about Joseph II's reforms. The Berlin philosopher was skeptical and worried that despite promises the edict would not lead to the Jews' liberation in the Austrian Empire.

\footnotetext{
Von der Toleranz, welche in allen Zeitungsblättern so sehr herrscht, habe ich bei weitem noch die günstige Meinung nicht, die Sie davon zu erkennen geben. So lange noch das Vereinigungssystem im Hinterhalte lauert, scheint mir diese Toleranzgleißnerei noch gefährlicher als offene Verfolgung. Montesquieu hat schon in seinen lettres persannes [Persian Letters - A. L.], wo ich nicht irre, den verderblichen Gedanken gehabt, daß das beste Mittel zur Bekehrung nicht Härte und Verfolgung, sondern Sanftmuth und Duldung sei; und mir kommt es vor, als wenn dieses eigentlich, und nicht Weisheit und Menschenliebe, jetzt das herrschende Principium sein wolle. ${ }^{111}$
}

Mendelssohn understood as early as 1783, that the Enlightenment's promises of tolerance and Jewish assimilation were not the answer to the Jews' endangered situation. The Berlin philosopher saw that keeping its own religious identity were key to Judaism's survival. Nevertheless, almost the whole Jewish population changed its norms amid the Enlightenment's assimilationist pressure. Naftali Herz Homberg was just one of the many who contributed to Judaism's Germanization and Christianization, with a view to them being accepted within majoritarian society. As we learn from later developments in Central and Eastern European history though, neither assimilation nor other acculturation strategies saved the Jews from being treated as 'the other'.

109 Kieval, Languages of Community (cf. n. 35), 60.

110 Cf. Mendelssohn, Moses Mendelssohn’s Briefe an Herz Homberg (cf. n. 19), 654.

111 Moses Mendelssohn an Herz Homberg. 01.03.1784. In: Georg Benjamin Mendelssohn (Ed.): Moses Mendelssohn‘s gesammelte Schriften. Vol. 5. Leipzig 1844, 675-678, here $676 \mathrm{f}$. 